YEARBOOK
of ANTITRUST
and REGULATORY
STUDIES
www.yars.wz.uw.edu.pl
Peer-reviewed scientific periodical, focusing on legal and economics issues of antitrust and regulation. Creative Commons Attribution-No Derivative Works 3.0 Poland License

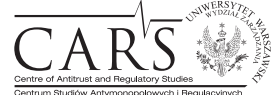

Centre of Antitrust and Regulatory Studies, University of Warsaw, Faculty of Management www.wZ.uw.edu.pl

\title{
Is the forcing of services on suppliers an abuse of a dominant position? Case comment to the judgment of the Supreme Court of 19 February 2009 - DROP (Ref. No. III SK 31/08)
}

\section{Facts}

In the decision RPZ 21/2005 issued on 21 July 2005, the UOKiK President established an infringement of Article 8(2)(5) and (1) of the Act of 15 December 2000 on Competition and Consumer Protection ${ }^{1}$ (hereafter, Competition Act 2000) by the poultry producer DROP S.A. (hereafter, DROP). DROP was found to have abused its dominant position in the purchase markets of duck hatching eggs and goose hatching eggs. The competition authority identified abuses in the form of:

- counteracting the formation of conditions necessary for the emergence or development of competition (in this case - in the veterinary services market), and

- the imposition of unfair trading conditions.

The same forms of abuse are now listed in Article 9(2)(5) and (1) of the Act of 16 February 2007 on Competition and Consumer Protection ${ }^{2}$ (hereafter, Competition Act 2007). The UOKiK President analysed the agreements between DROP and its suppliers of duck hatching eggs and goose hatching eggs. According to UOKiK's analysis, DROP had imposed an unfair contractual provision requiring its suppliers to only use veterinary prevention treatments (in particular vaccinations) performed by SSW, a veterinary surgeon appointed by DROP.

The decision was appealed to the Court of Competition and Consumer Protection (hereafter, SOKiK) but the appeal was dismissed in its entirety as groundless. The judgment of SOKiK, upholding the decision in all its aspects, was appealed to the Court of Appeals in Warsaw by DROP, which sustained its original charges. The Court of Appeals agreed with SOKiK that the UOKiK decision was correct.

Subsequently, DROP filed a cassation appeal to the Polish Supreme Court claiming that the judgment of the Court of Appeals violated procedural as well as material laws such as Article 8(2)(5), Article 8(2)(1) and Article 1 of the Competition Act 2000. The Supreme Court in its judgment of 19 February 2009 settled the dispute in

\footnotetext{
1 Consolidated text: Journal of Laws 2005 No. 244, item 2080, as amended.

2 Journal of Laws 2007 No. 50, item 331, as amended.
} 
favour of DROP and quashed both earlier judgments as well as the original decision issued by the UOKiK President. While the Supreme Court found that the allegation of an infringement of Article 8(2)(5) and Article 8(2)(1) was justified under the circumstances of the case, it rejected DROP's argument that procedural laws and Article 1 of the Competition Act 2000 were infringed.

\section{Key legal problems of the case and key findings of the Supreme Court}

\section{Foreclosure of the veterinary services market}

The Supreme Court stated that DROP's conduct in the purchase markets of duck hatching eggs and goose hatching eggs had not counteracted the formation of the conditions necessary for the emergence or development of competition in the veterinary services market. In particular, DROP's conduct was not seen as foreclosing the veterinary services market to the competitors of SSW. Market foreclosure effects can occur in the market where the dominant firm acts (and where it holds a dominant position) or on a derivative or linked market ${ }^{3}$ called by Polish jurisprudence a related/ neighbouring market. The latter type of foreclosing practices is known as the 'transfer of dominance' or 'leveraging'4.

Transfer of dominance is an issue that received some attention in the judgment considered here. In the opinion of the Supreme Court, to classify a practice as a transfer of dominance, it must be shown that the dominant firm has an economic interest (incentive) in the foreclosure of the related market. Such an economic interest may exist in circumstances where the dominant firm is engaged in leveraging practices (affecting a related market) in order to:

- protect its dominant position in the primary market,

- strengthen (enhance) its pre-existing position in the related market,

- extend its activities to the related market ${ }^{5}$,

3 See e.g. the judgments of SOKiK: of 4 March 2008, XVII Ama 70/07, not reported; of 4 January 2008, XVII Ama 72/07, not reported ('the related market'); the judgment of the Antimonopoly Court of 11 December 2000, XVII Ama 45/00, LEX no. 56103 ('the neighbouring market'); the judgment of SOKiK of 4 August 2008, XVII Ama 4/08, not reported ('the derivative market'); the judgment of SOKiK of 9 November 2006, XVII Ama 114/05, not reported ('the linked market').

${ }^{4}$ See more on this subject: F. Alese, Federal Antitrust and EC Competition Law Analysis, Aldershot 2008, p. 229-275; K. N. Hylton, Antitrust Law. Economic Theory and Common Law Evolution, New York 2003, p. 202-212; K. Kohutek, [in:] K. Kohutek, M. Sieradzka, Ustawa o ochronie konkurencji i konsumentów. Komentarz [Act on Competition and Consumer Protection. Commentary], Warszawa 2008, p. 346-348. See also T. Skoczny [in:] T. Skoczny, A. Jurkowska, D. Miąsik (eds.), Ustawa o ochronie konkurencji i konsumentów. Komentarz [Act on Competition and Consumer Protection. Commentary], Warszawa 2009, p. 610-611.

${ }^{5}$ See also the judgment of the European Court of Justice of 6 March 1974, joined Cases 6 and 7/73 Instituto Chemioterapico Italiano S.p.A. and Commercial Solvents Corporation v Commission [1974] ECR 223. 
and/or

- organise the related market and in particular, to set up the rules for its functioning ${ }^{6}$,

- make firms that operate in the related market dependent on the dominant company, that is, compel them to cooperate with it as a condition of their acting in the related market ${ }^{7}$.

The Supreme Court seemed to be of the opinion that the lower instance courts and the UOKiK President failed to sufficiently prove the leveraging of dominance held on one market (purchase market of duck hatching eggs and/or purchase market of goose hatching eggs) onto another market (market for veterinary services). It should be noted first of all - respecting the general conclusion of the judgment - that DROP was not present on the market for veterinary services and did not show any intention to extend its activities onto that market, to organise that market and/or to make veterinary surgeons dependent on DROP. There was certainly no proven motive in this case that ultimately linked DROP's conduct to the protection of DROP's dominant position in the purchase markets for duck hatching eggs and goose hatching eggs.

The infringement of Article 8(2)(5) of the Competition Act 2000 has therefore not been seen as substantiated by the competition authority and lower instance courts. Moreover, as shown in the commented judgment, counteracting the formation of conditions necessary for the emergence or development of competition is reflected by the creation of entry barriers that are of fundamental importance for those concerned ('conditions necessary for...'). Agreeing with the conclusions reached by the Supreme Court, it is truly surprising that no attempt has been made by the UOKiK President to determine which conditions, necessary for the emergence or development of competition in the veterinary services market, could not have emerged due to DROP's conduct in the purchase markets of duck hatching eggs and goose hatching eggs.

\section{Relevant markets}

According to the UOKiK decision, the abuse of a dominant position by DROP in the purchase markets of duck hatching eggs and goose hatching eggs took the form of, inter alia, counteracting the formation of the conditions necessary for the emergence or development of competition in the veterinary services market. Consequently, the case concerns various markets with different characteristics.

The Supreme Court believed that the veterinary services market was not directly related to the purchase markets of duck hatching eggs and goose hatching eggs seeing as none of these two markets involved goods used in the same manufacturing cycle (raw materials - semi-finished goods - finished goods). The Court did not identify any 'common denominators' between them. Whether this reasoning is correct or not, the decision of the UOKiK President had a serious defect - while the authority identified

\footnotetext{
${ }^{6}$ See the judgment of SOKiK of 4 August 2008, XVII Ama 4/08, not reported.

7 See the judgments of SOKiK: of 3 March 2008, XVII Ama 43/07, not reported; of 13 June 2006, XVII Ama 59/05, not reported.
} 
some anticompetitive effects in the veterinary services market, it failed at the same time to substantiate them properly. The UOKiK President should have performed a prior analysis of all relevant markets within the meaning of Article 4(8) of the Competition Act 2000 (currently Article 4(9) of the Competition Act 2007), considering both their product and geographic terms. Instead, the justification of the final decision did not consider the veterinary services market as a relevant market at all.

The UOKiK President failed also to define, for the purposes of this case, the geographic extent of the scrutinised veterinary services as national, regional or local (in particular, as a market with the same geographical scope as the purchase markets of duck hatching eggs and goose hatching eggs). Traditionally, the competition authority ${ }^{8}$ and courts ${ }^{9}$ used to show a willingness to define narrow product markets. By contrast, the related market was defined here very broadly (in product terms) including all veterinary services (not only those limited to prevention treatments) provided for all species (not limited to ducks and/or geese).

Thus, the Supreme Court expressed the opinion that 'warding off' suppliers of hatching eggs from veterinary prevention treatments performed by entities other than SSW could not have an appreciable effect on competition in such broadly defined market of veterinary services. It should be mention here that according to their agreements with DROP, its suppliers were indeed allowed to purchase veterinary services from SSW's competitors, as long as they were not prevention treatments. At the same time, suppliers not bound by the scrutinised agreements were free to purchase all their veterinary services from the competitors of SWW.

To pursue this thought a little further, DROP operated in a competitive environment. It had a dominant market share but it did not hold a monopolistic position ${ }^{10}$ and so its suppliers could choose freely from among several purchasers of hatching eggs. However, it is impossible to properly analyse the competitiveness of this market due to the scarcity of the available data. The UOKiK President did not reveal the respective market shares of the relevant market participants in the published decision of 21 July 2005. Regardless, DROP's suppliers were able to choose a purchaser that was not necessarily interested in forcing them to use the veterinary services of SSW.

${ }^{8}$ See e.g. decision RWR 28/2009 issued on 2 November 2009, or decision in the commented case.

${ }^{9}$ See the judgments of the Antimonopoly Court: of 23 October 2002, XVII Ama 133/01, (2004) 4 Wokanda 49; of 26 October 1994, XVII Amr 24/94, (1995) 8 Wokanda 55; see also the judgments of SOKiK: of 14 September 2006, XVII Ama 71/05, Official Journal of UOKiK 2006 No. 4, item 61; of 28 November 2008, XVII Ama 107/07, Official Journal of UOKiK 2009 No. 1, item 6; of 18 January 2007, XVII Ama 101/05, Official Journal of UOKiK 2007 No. 3, item 33. This is analogous to the European courts practice; see e.g. the judgment of the ECJ of 13 November 1975, 26/75 General Motors Continental NV v Commission [1975] ECR 1367.

${ }^{10}$ See K. Kohutek, 'Zarzut nadużycia pozycji dominującej na rynku usług weterynaryjnych' ['Allegation of an Abuse of a Dominant Position in the Veterinary Services Market'] (2009) 4 Glosa 98. 


\section{Imposition of unfair trading terms}

The second question that the Supreme Court had to address was whether DROP, which held a dominant position in the relevant markets, was imposing unfair trading conditions on its suppliers. The Court had to decide whether trading conditions regarding veterinary prevention treatments were unfair and whether they had been imposed on the suppliers of DROP.

It was noted in the concluding remarks of the commented judgment that the behaviour in question was not the practice referred to in Article 8(2)(1) of the Competition Act 2000. Even if the scrutinised contractual provisions could be seen as unfair, the Court did not believe that it was proven that they were imposed by DROP on its suppliers. The concept of 'imposition' means the elimination of another's choice as the result of the market power of a dominant firm. To assess whether unfair trading terms had been indeed imposed, the UOKiK President should have considered whether a reasonable contractor would have enter into such an agreement (obliging it to only use SSW's veterinary prevention treatments). In the opinion of the Supreme Court, the competition authority failed to prove that DROP's suppliers were not involved in the decision making process in that regard or that they were unable to exercise their choice in the process of contract negotiations. The absence of contract negotiation may be an expression of the lack of choice available to contractors and, consequently, of the imposition of trading terms ${ }^{11}$. It must be emphasised however, that the following behaviours do not appear to show the absence of choice:

- where a contractor does not make any attempt to negotiate trading terms,

- where a contractor forms irrational expectations concerning trading terms,

- where a contractor does not answer a dominant firm's proposal to put forth a draft contract and a dominant firm prepares its own draft $^{12}$.

The Supreme Court's analysis of Article 8(2)(1) of the Competition Act 2000 posed also an important additional question. Under this provision, the abuse of a dominant position may consist, in particular, of the direct or indirect imposition of unfair prices, including exorbitant prices or excessively low prices, far-off payment dates or other trading conditions. The lower instance courts concluded that a mere imposition of trading conditions other than unfair prices might be sufficient to constitute an infringement of Article 8(2)(1) of the Competition Act 2000. Thus, the imposition by a dominant firm of not just unfair trading conditions but in fact any trading conditions at all was deemed to be contrary to Article 8(2)(1). The Supreme Court did not refer directly to the approach taken by the lower instance courts but even so, two types of objections should be raised in this respect.

Considering the wording of Article (2)(1) of the Competition Act 2000, it is certainly true that the adjective 'unfair' is placed directly in front of the noun 'prices'. However,

11 See the judgment of the Court of Appeals in Warsaw of 6 September 2006, VI Ca 196/06, not reported.

12 See the judgment of the Antimonopoly Court of 6 November 2000, XVII Ama 3/00, (2002) 6 Wokanda 51. 
it is not necessary to repeat it in the later part of the sentence to extend its applicability to the term 'other trading conditions'. A differentiation of classes of trading conditions referred to in Article 8(2)(1) would not be justified in light of the objectives of competition law nor in the context of the jurisprudential construction of the notion of an abuse of a dominant position ${ }^{13}$. In principle, an imposition of fair trading conditions on a contracting party is not an abuse of a dominant position. It makes no sense to apply here an out-of-context literal interpretation of Article 8(2)(1) and by doing so, to limit the application of the adjective 'unfair' to price considerations only.

Secondly, the wording of the Polish provision is closely modelled, even though not identical, on Article 102(a) of the Treaty on the Functioning of the European Union. According to this rule, an abuse of a dominant position may consist, in particular, of 'directly or indirectly imposing unfair purchase or selling prices or other unfair trading conditions'. The European legislature was 'industrious' in this respect and attached the adjective 'unfair' to both prices as well as other trading conditions. Notwithstanding the fact that European competition law was not applicable to the market practices of DROP, it is clear that Polish courts use it as guidance when determining domestic cases $^{14}$.

\section{Unfairness of trading terms}

The UOKiK President regarded the contractual terms in question as unfair, that is, breaking binding or conventional norms. However, in the opinion of the Supreme Court, both legal and economic criteria must be used to assess unfairness. One has to look at the entirety of the circumstances in which an agreement was concluded. An unfair term is, without a doubt, the imposition of behaviour contrary to the law, a problem that has not arisen in this case.

The UOKiK President compared the agreements between DROP and its suppliers to contracts concluded between other entities of the same trade. Seeing as similar provisions were not found in other contracts, the competition authority concluded that DROP's terms had been unfair. The Supreme Court could not agree with this reasoning and contradicted it by the following considerations. A contractual term is not unfair simply because it is not applied in the relevant market or in trading relations of a given sort.

On the other hand, an unfair term is one shifting costs from a dominant firm to its contractors. Contrary to the conclusions of the UOKiK President, this did not occur

13 See also K. Kohutek, 'Zarzut nadużycia pozycji...', p. 107-108.

14 In its judgments of 6 December 2007, III SK 16/07, (2009) 1-2 OSNP 31, and of 9 August 2006, III SK 6/06, (2008) 1-2 OSNP 25, the Supreme Court dealt with the relationship between the European and Polish competition laws. The court, invoking also the Regulation 1/2003, has explained that where the current Articles 101 and 102 of the Treaty on the Functioning of the European Union are inapplicable in a given case (e.g. because of a lack of impact on the trade between the Member States), the Polish courts should obviously apply the national law. However, in such situations the European competition rules may be a 'source of intellectual inspiration'. 
in this case. It seems necessary to warn those who might be apt to forget here that the costs of veterinary prevention treatments are customarily borne by the suppliers of hatching eggs (as owners of ducks and geese which 'produce' those eggs) and not by their purchasers.

An unfair term is also one that increases the costs of running a business by a contractor, one that prevents contractors from decreasing their costs or an imposed term that is not exacted by a dominant firm from itself nor from its associates ${ }^{15}$. However, a simple limitation of a contractor's freedom to act is not sufficient to prove 'unfairness' - the actual or potential impact on competition in that market must be identified at the same time. Not only did the UOKiK President fail to identify such impact in this case, the authority did not even prove that the obligation to only use SSW treatments has in fact increased the supplier's operating costs.

\section{Final remarks}

The DROP case concerned a number of complex legal issues relating to some of the market practices prohibited by the current Article 9(2)(5) and (1) of the Competition Act 2007. The judgment of the Supreme Court addressed several important legal questions on relevant market foreclosure as well as on the imposition of unfair trading terms. It is also likely to provide useful guidance for entrepreneurs on some important commercial issues that are only rarely subject to juridical scrutiny.

In conclusion, the Supreme Court ruled that the abuse charges concerning DROP had not been sufficiently substantiated by the UOKiK President. The decision failed to show that DROP had any economic interest in the foreclosure of the related market for veterinary services nor was it proven that it had actually imposed the said trading terms on its suppliers. The Supreme Court was right to state that a contractual term is not unfair simply because it is not applied in the relevant market or in trading relations of a given sort. The Court stated also that the imposition of trading terms which were not unfair did not infringe the current Article 9(2)(1) of the Competition Act 2007. Taking any other approach would not be consistent with the objectives of competition law and the jurisprudential construction of the notion of an abuse of a dominant position. It might have been worth considering whether the scrutinised conduct could not have been treated as an abuse of DROP's dominance by virtue of tying ${ }^{16}$ but this objection is more formal than substantial because the UOKiK President did not introduce the prohibition of tying into the legal basis of its decision.

\section{Dr. Anna Piszcz.}

Faculty of Law, University of Białystok

15 See the judgment of SOKiK of 18 December 2007, XVII Ama 11/07, not reported.

16 Tying is generally regarded as a separate form bundling; see J. P. Choi, 'Antitrust Analysis of Tying Arrangements' [in:] J. P. Choi (ed.), Recent developments in antitrust: theory and evidence, Cambridge (Massachusetts) 2007, p. 61. 